\title{
Effect of chalcones in the modulation of Trichophyton rubrum cell wall synthesis genes
}

\author{
Tamires Ap. Bittencourt, Juliana Simões Martins", Mariana Abreu, Tatiana Komoto, Luiz Felipe Bortolotto, \\ Yasmim Crivelenti, Thais Mesquita, Vitor Pinhanelli, Bruna Cantelli, Mozart Marins, Ana Lucia Fachin \\ From 5th Congress of the Brazilian Biotechnology Society (SBBIOTEC) \\ Florianópolis, Brazil. 10-14 November 2013
}

\section{Background}

Trichophyton rubrum is a dermatophyte that causes mostly superficial mycoses in skin, hair and nails, but an invasive course has been described in immunocompromised patients [1]. The resistance to usual antifungal drugs has been observed in T.rubrum what drives an increasing demand for new antifungal drugs. Chalcones are flavonoids found in plants that exhibit pronounced antifungal activity, most likely acting on the cell wall $[2,3]$. The aim of this study was to evaluate the modulation of expression of genes involved in cell wall synthesis of T.rubrum in the presence of chalcones.

\section{Methods}

The T. rubrum strain H6 (ATCC MYA3108) was submitted to standard techniques for fungal manipulation and growth for 15 days as described previously by Fachin et al.[4]. The solution containing $5 \cdot 10^{6}$ conidia/ml of $\mathrm{H} 6$ T.rubrum strain was inoculated into $50 \mathrm{ml}$ of liquid Sabouraud medium in the presence of $1.95 \mathrm{mg} / \mathrm{ml}$ of trans-chalcona metoxichalcona and controls aculeacin $(0.24 \mathrm{mg} / \mathrm{ml})$ and amphotericin $(3.9 \mathrm{mg} / \mathrm{ml})$ in a rotatory shaker at $28^{\circ} \mathrm{C}$. After 8 hours of antifungal exposition, the RNA was extracted, converted into cDNA and was used in the experiments of real-time PCR. Expression levels were calculated by the comparative $\mathrm{Ct}$ method using 18S rRNA as normalizer gene and untreated mycelia as reference, according Bitencourt et al [5].

\section{Results and conclusion}

The genes evaluated were DW699324 encoding the catalytic subunit of beta 1,3-glucan synthase in Aspergillus fumigatus [6]. The gene DW703091 ( $\beta$-1,3-glucanosiltransferase) that is involved in the remodeling of 1,3- glucan in yeast [7]. The DW687782 is the gene encoding structural proteins of the membrane and the cell wall and is essential for the growth of Candida albicans [8]. The three genes of T.rubrum were induced in the presence of trans-chalcone, metoxichalcona and control aculeacin (acts on the wall) and were repressed in the presence of amphotericin (acts on the membrane). Thus, the antifungal effect of chalcones against T.rubrum may be related to modulation of these genes involved in cell wall synthesis.

\section{Acknowledgements \\ This study was supported by grants from Fundação de Amparo à Pesquisa do Estado de São Paulo (2011/06124-8) and fellowship granted to TAB (2012/02920-7) and LFBB (2012/15862-5); CNPq (PIBIC fellowship granted to MHA), PET MEC (fellowships granted to TBM, BAMC, YDC) and CAPES through fellowship granted to FRB and TTK. We thank the staff of the Biotechnology Unit, UNAERP.}

Published: 1 October 2014

\section{References}

1. Ameen M: Epidemiology of superficial fungal infections. Clinics in dermatology 2010, 28(2):197-201.

2. Nowakowska Z: A review of anti-infective and anti-inflammatory chalcones. Eur J Med Chem 2007, 42(2):125-137.

3. Boeck P, Leal PC, Yunes RA, Filho VC, Lopez S, Sortino M, Escalante A, Furlan RL, Zacchino S: Antifungal activity and studies on mode of action of novel xanthoxyline-derived chalcones. Arch Pharm 2005, 338(2-3):87-95.

4. Fachin AL, Ferreira-Nozawa MS, Maccheroni W Jr, Martinez-Rossi NM: Role of the $A B C$ transporter TruMDR2 in terbinafine, 4-nitroquinoline $\mathrm{N}$-oxide and ethidium bromide susceptibility in Trichophyton rubrum. $J$ Med Microbiol 2006, 55(Pt 8):1093-1099.

doi:10.1186/1753-6561-8-S4-P82

Cite this article as: Bittencourt et al: Effect of chalcones in the modulation of Trichophyton rubrum cell wall synthesis genes. BMC Proceedings 2014 8(Suppl 4):P82. 